\title{
ESA SOMBRA QUE SE FILTRA POR TODAS PARTES: GALDÓS Y BUÑUEL / THAT SHADOW FILTERING EVERYWHERE
}

\author{
José Carlos Vela Bueno \\ Consorcio de Universidades Americanas en Madrid \\ (Albany, NYU, BU y Middlebury College)
}

Recibido: 21/11/2020

Resumen: La sombra es lo reprimido como olvidado, lo restringido, lo invisibilizado. Este texto trata sobre dicha sombra tanto en la psique como en los cuerpos humano y social. Lo desplazado e invisibilizado exige tener voz y encuentra en las distintas formas de expresión artística una de las esferas privilegiadas para manifestarse. Las obras de Benito Pérez Galdós y de Luis Buñuel así lo muestran; la expresión de lo restringido e invisibilizado es uno de los vínculos más poderosos entre las obras de ambos autores.

Palabras clave: Galdós, Buñuel, Psicoanálisis, Freud, Jung, Kayser, represión, otredad, sombra, cine y literatura.
Aceptado: 10/12/2020

\begin{abstract}
The shadow is the repressed as forgotten, the restricted, the invisible. This text deals with said shadow both in the psyche as well as in the human and social bodies. What is displaced and invisible requires a voice and finds in the different forms of artistic expression one of the privileged spheres to express itself. The works of Benito Pérez Galdós and Luis Buñuel show this; the expression of the restricted and invisible is one of the most powerful links between the works of both authors.
\end{abstract}

Vela Bueno, José Carlos. «Esa sombra que se filtra por todas partes: Galdós y Buñuel». Cultura de la República. Revista de Análisis Crítico, 4 (diciembre 2020): 20-36. DOI: https://doi.org/10.15366/crrac2020.4.002. ISSN: 2530-8238 
El modelo académico más frecuentemente seguido para aplicar la teoría al análisis de textos literarios y fílmicos conlleva una previa exposición del pensamiento del intelectual cuyas ideas se toman como marco para dicho estudio. Esto presupone por parte del profesor o estudiante que lleva a cabo tal análisis textual, comprensión e identificación con las opiniones del pensador cuyas ideas se esgrimen. Pero cabe otro uso de la teoría que no conlleve necesariamente la exégesis e implícita apología del texto de partida, que es el de la inspiración. Cuando digo inspiración no me refiero a recibir una luz de las musas o de la interioridad creativa, me refiero a un estímulo intelectual recibido a través de una lectura. Hay textos que te incitan a ilustrarte mejor y de forma distinta, sin que eso signifique una identificación total o parcial con su contenido. Al decir que te inspiras en alguien no te arrogas un conocimiento absoluto del original. Supone que la lectura te insufla, sopla, ideas, pero no te da un todo coherente que debes seguir y aplicar en su integridad. Esto me sucede con la lectura de Carl Jung, no coincido con su pensamiento en muchas de las bases que sustentan el mismo, como, por ejemplo, el inconsciente colectivo, tampoco estoy de acuerdo con muchas afirmaciones que él y, sobre todo, varios de sus seguidores hicieron en materia de género, tampoco coincido con sus afirmaciones sobre historia, pero, aun así, su lectura me ha sido enormemente inspiradora en algunos aspectos, sobre todo, en los simbólicos. Y hay uno de sus símbolos (siguiendo su terminología debería decir arquetipos) que aparece en el título de estas líneas, «la sombra«, que siempre me ha producido una especial estimulación intelectual.

Entre los arquetipos, según Jung, se puede destacar la sombra, que, expresada con el insuficiente lenguaje conceptual, viene a ser lo inconsciente, tanto en el plano personal como en el colectivo. Este arquetipo se puede expresar de distintas maneras, no sólo a través de la sombra en sí, puede aparecer también simbolizado por el agua, en la que tras su superficie donde encontramos nuestra propia imagen, nuestro reflejo, aparecen «seres vivientes... peces, inofensivos habitantes de la profundidad [...] inofensivos si el lago no fuera para muchos espectral» (Arquetipos 30).

La sombra en este sentido nos conduce a la división del sujeto, con todo lo que esto conlleva de áreas aceptadas por él mismo y la colectividad en la que vive, y zonas de su psique de difícil aceptación, según Birkhäuser-Oeri, la sombra es expresión de «los aspectos oscuros, moralmente reprobables, o simplemente primitivos de la psique, que a menudo son inconscientes» (35); según esta seguidora de Jung, «la figura de la sombra puede referirse a todas las facetas que la psique percibe como inferiores» (35). 
La sombra jungiana no solo alude a aspectos regresivos de lo inconsciente, también puede aludir a áreas creativas y biófilas que no pueden ser expresadas en determinados contextos. Pero en todos los casos alude a lo no visible, utilizamos la expresión estar en la sombra para definir lo que queda oculto o poco perceptible. Esta connotación de quedar oculto nos acerca a lo siniestro freudiano. Siniestro que es el término con el que se ha traducido al castellano la palabra alemana unheimlich. Según Freud: «lo unheimlich, lo siniestro, procede de lo heimisch, lo familiar, que ha sido reprimido» (Lo siniestro 2501). Lo reprimido en sentido freudiano es lo que ha sido olvidado por doloroso o inconveniente, lo que ha quedado encerrado en el laberinto del inconsciente, lo que ha quedado oculto, no visible.

Pero en el uso que voy a hacer en estas páginas del término sombra no me limitaré solamente a lo reprimido psíquico, entendido como lo olvidado, me referiré también a todo lo restringido socialmente, las clases bajas, los grupos marginales, las áreas del cuerpo bajo, el lenguaje no apropiado según que contexto. No solo entenderé la sombra desde el punto del vista de lo subalterno, también tomaré como sombra todos los deseos conocidos por el sujeto y que por inconveniencia social o por moral debe intentar controlar o dejar atrás. Me refiero por tanto a todo un mundo que no se expresa abiertamente porque algún tipo de inconveniencia lo prohíbe. A toda la sombra que cualquier afirmación, que cualquier paso firme, al instaurarse a sí misma frente a la luz, deja en su entorno. Sombra es el mundo de lo no expresado y exteriorizado pero que reclama visibilidad. Uno de los caminos de salida que ha encontrado dicho universo no expresable es el arte. No habría, por ejemplo, arte grotesco sin sombra.

El mundo de las sombras es el ámbito de lo reprimido, en el doble sentido de la palabra como olvidado (en sentido estrictamente freudiano) y como prohibido. Pero quedan otros ámbitos como ciertas partes del cuerpo o ciertos grupos sociales que no son contundentemente reprimidos pero que si son apartados y limitados. Nadie se olvida de su sistema urinario, ni es prohibido su uso, no son prohibidos los lugares destinados a la evacuación, pero son lugares restringidos. El mundo de la sombra es el mundo de la restricción, bien por represión, bien por apartamiento.

Dentro del mundo de lo restringido juega un papel importante el cuerpo bajo. Ese cuerpo que sumimos en la sombra porque lo tapamos como los genitales, o lo cerramos, como la boca, ese cuerpo que emite fluidos, pero también el cuerpo de la rugosidad. Ese cuerpo que es sombra es lo opuesto al cuerpo clásico, liso, pulido, simétrico y con bases geométricas. No todo el entendimiento de la belleza 
occidental es clásico, pero el clasicismo ejerce un fuerte influjo en la forma de ver la fisonomía que Occidente ha diseminado por el mundo. Un cuerpo pulido es un cuerpo sin arrugas, poros o cualquier otro accidente que presente la piel, una boca clásica es una abertura cerrada y por ello sin dientes, y si estos aparecen no presentarán irregularidades o caries. Así Hegel, en un texto citado por Byung - Chul Han entiende la belleza como pudorosa supresión, curiosamente como supresión de todo lo vital, y prescribe al ropaje la tarea de ocultar lo «superfluo de los órganos que, por supuesto necesarios para la autoconservación del cuerpo, para la digestión, etc., son sin embargo superfluos para la expresión de lo espiritual» (26). Esta propuesta de tapar el cuerpo con ropa sería llevar hasta el extremo la línea de supresión clasicista.

Pero la sombra no se contenta con estar en su sitio y siempre quiere filtrarse por todas partes, de hecho nunca ha dejado de estar presente de una forma u otra en la representación del cuerpo; así, a finales del siglo XVI con Caravaggio, por ejemplo, las pieles curtidas por el sol y el viento de los pobres invaden el espacio de lo sagrado, las arrugas, las uñas oscuras y mugrientas, las barbas no recortadas, el pelo sucio y revuelto, marcará la retórica religiosa durante varias décadas

El cine de Buñuel nos ofrece un amplio repertorio del cuerpo de la sombra. No del cuerpo de los genitales, en esto era pudoroso, pero si del cuerpo de la «autoconservación», sobre todo de la boca. Son frecuentes en su cine los primeros planos de las caras de los marginados con las bocas abiertas a las que les faltan dientes. Por ejemplo en Los olvidados cuando Jaibo le habla como un líder de pie a los niños pobres sentados, muestra en picado las caras de los chicos con las bocas abiertas, algunas de ellas desdentadas. En Viridiana son diversas las ocasiones en que la cámara se acerca en primeros planos muy cerrados a las caras de los mendigos cuyas texturas se resaltan por el blanco y negro. Mucho se mira la boca de Poca, o la boca desdentada y en exceso gesticulante del leproso, también se mira con detenimiento la cara del ciego y sus ojos dañados, algo que también se había hecho con Don Carmelo en Los olvidados. No se trata solo de mostrar con naturalismo el cuerpo de los pobres, se trata de dar una mirada lo más descarnada posible.

Buñuel sintió una gran admiración por Pérez Galdós, lo que le llevó a decirle a Max Aub: «Es la única influencia que yo reconocería, la de Galdós, así, en general, sobre mí» (118). Una de las cosas que vinculan a ambos creadores es la representación de la pobreza como un mundo lúgubre y sórdido, como bien dice Víctor Fuentes, ambos autores presentan a los pobres «sin ninguna idealización» $\mathrm{y}$ «con toda la fuerza corruptora de la miseria» (175). El mundo de la pobreza 
en Viridiana, aunque no sea una versión argumental explícita de ninguna novela del escritor canario, nos invoca Misericordia, Halma, Angel Guerra y Nazarín. Los pobres de esta última novela no solo se parecen a los del filme con el mismo nombre, también nos recuerdan los de Viridiana. Llamo la atención sobre la presentación de la corrala del comienzo de la novela protagonizada por el benigno cura, no tanto en situaciones y personajes concretos como en el tono sórdido en que la miseria se presenta en ambos casos. En ambos el cuerpo de la gente y de las cosas es expresado a través de su rugosidad e irregularidad anticlásicas. En el comienzo de la novela, en la descripción de la corrala, el narrador utiliza un lenguaje de una fortísima crudeza para describir la pobreza del lugar, tales son los tintes de dicha aspereza que nos recuerdan el tono de las descripciones de El Buscón:

El patio, mal empedrado y peor barrido, como el portal, y con hoyos profundos, a trechos hierba raquítica, charcos, barrizales o cascotes [...]; puertas de cuarterones con gateras tan grandes que por ellas cabrían tigres si allí los hubiese; trozos de ladrillo amoratado, como coágulos de sangre;... (X, 10-11).

El estilo acumulativo de Quevedo se manifiesta muy bien en esta descripción de la señora Chanfaina, con esta cascada de conceptismos degradantes:

...la panza voluminosa, los brazos hercúleos, el seno emulando en proporciones a la barriga y cargando sobre ella, por no avenirse con apreturas de corsé, el cuello ancho, carnoso y con un morrillo como el de un toro, la cara... abultada, barroca, llamativa, como la de una ninfa de pintura de techos, dibujada para ser vista de lejos, y que se ve de cerca $(X, 13)$.

Todo nos transmite aquí sensación de corrupción y fealdad: la tuerta andrajosa, los ciegos, tan importantes en Buñuel -uno de ellos con un violín «que no tenía más de dos cuerdas» $(\mathrm{X}, 12)-$, personajes disfrazados pobremente para el carnaval -uno de los cuales lleva «un pañuelo cogido por las cuatro puntas, lleno de higos que más bien boñigas parecían» $(\mathrm{X}, 12)-$, una anciana paralítica -cuya cara era «ampliación de una castaña pilonga» $(X, 12)-$, etcétera.

La descripción galdosiana es claramente selectiva y dirigida a enfatizar los aspectos degradantes de lo descrito, es lo que Chatman define como descripción explicita, propia de la literatura. La narración en el texto tomado de Nazarín se detiene para decirnos lo feo que es este lugar y sólo vemos aquellos aspectos degradantes de las cosas y la gente que explícitamente es señalada por el narrador que nos conduce en unas direcciones y no en otras. De la anciana de Galdós sabemos que es paralítica y que tiene una cara de castaña, pero, no sabemos cómo es su nariz, algo que sí sabríamos de un personaje cinematográfico al que veríamos la cara por entero y sin necesidad de suspender la narración. 
En cine, la descripción es tácita, no tiene carácter selectivo, lo vemos todo, no detiene la narración de unos hechos para dirigirnos a unos rasgos concretos del personaje, según se narra se lo describe, no deja nunca de describir:

\begin{abstract}
It is not that cinema cannot describe; on the contrary, it cannot help describing [...] it cannot present a minimal verbal account like «a woman entered the room.» Rather it must provide an exhaustive set of visual details, transcribable by a potentially unlimited verbal paraphrase: «A woman with a roman nose high cheekbones, and blond hair piled elaborately on her head... (Chatman, 40).
\end{abstract}

Sin embargo, Chatman admite que la descripción en imágenes puede en determinados momentos servirse de ciertos usos de la cámara para aproximarse a lo explícito de la literatura. Es decir, puede aproximarse a ciertas zonas del cuerpo y enfatizar esto a través de la angulación.

En Viridiana nadie, ni en el guion siquiera, hace uso de la palabra para detallar la fealdad de los mendigos, los vemos y, para que su fealdad se haga más patente, se usan primeros planos y planos medios cortos, lo que significa mucho en Buñuel, pues su cine se caracteriza por el uso de la planificación clásica en la que abundan los llamados «planos americanos». Es ahí, con el uso de los planos cortos y de un sutil, nada ostentoso, uso de los ángulos en contra picado, donde se acerca a los usos degradatorios de la descripción de Benito Pérez Galdós.

La visualidad en este caso toma unas connotaciones que hacen lo sórdido, o sea, lo degradante, especialmente intenso. La cámara se acerca obsesivamente, de manera morbosa, a la «fealdad» de los pobres (entiéndase que cuando digo fealdad, me refiero a distancia con respecto al ideal clásico de belleza, no a mis gustos sobre quien es guapo o feo).

Recordemos como desde el primer momento en que los mendigos entran en escena, la cámara persigue la cara del Poca que nos conduce al resto del grupo, a los que vemos juntos en un plano medio suavemente en contra picado. Recordemos también como a partir de ese momento, se nos ponen ante los ojos diversos planos próximos de la fealdad del ciego. Ese mundo de la podredumbre fascinó a Buñuel ya en Los olvidados, como he dicho, y en Las Hurdes, tierra sin pan, donde junto con la motivación política convive una tendencia de expresión de la sombra.

Ambos creadores supieron cruzar la sombra (es muy distinto cruzar la sombra de coquetear con la sombra que es lo que suele hacer hoy en día, pero esto es algo que exigiría otro ensayo diferenciado). La diferencia en la forma de cruzar la sombra entre ambos creadores reside, por lo general, no necesariamente siempre, en el grado de crudeza, Buñuel se sumergió en ella con una dureza mayor que Galdós. Esta comparación que llevo a cabo a partir de este instante, no va 
dirigida tanto al placer comparativo, como a profundizar en el cine de Buñuel a través de su forma de enfatizar la sombra en lo que llamo sus filmes galdosianos. Se sobreentiende que no hago de la crudeza un índice de calidad artística, sino una herramienta de profundización.

Es esta fuerza de lo emocional en su mayor crudeza, la que le da el carácter diferenciador a su versión cinematográfica de Nazarín. Es dura esa imagen, que no se corresponde con el final de la novela, en la que Nazarín camina hacia presidio y por el mismo camino pasa Beatriz en el carro del hombre que la maltrata y al que la hemos visto ciegamente entregada al principio de la película. De hecho, a estos dos amantes y su relación sadomasoquista nos los pone enfrente al comienzo de la película, mientras que en la novela tenemos que esperar hasta el capítulo cuarto de la tercera parte para que aparezca ella. Buñuel efectivamente degrada el máximo posible a su personaje, no con un sentido paródico, sino por la búsqueda de las emociones más profundas y primarias del ser humano.

Vemos al comienzo del filme una aportación al argumento muy propia del director aragonés, en ella, la mujer sufre una crisis epiléptica mientras tiene una visión sadomasoquista, una pura emanación emocional inconsciente, próxima a los sueños tan frecuentes en la cinematografía de Luis Buñuel, en la que abiertamente se expresan sus deseos y los de Pinto con toda crudeza, cito por el guion (respeto, sangría y uso de mayúsculas de la copia del guion de la Filmoteca Nacional en su página 19):

BEATRIZ

Así quería verte, canalla [borrada a lápiz esta palabra en el guion]...viniendo a suplicar lo que no voy a darte... siempre quieres lo mismo, cochino...

PINTO

Te voy a dejar sin sangre y me voy a ir, me voy a ir con otras que valen más que tú... hija de la...

Ella ríe en un escalofrío.

\section{BEATRIZ}

Te gusto, ¿verdad? Te he robado la voluntad... aunque quieras no me puedes dejar... ¡cabestro!

No puede seguir hablando porque él la besa.

CLOSE UP

El beso. Beatriz de pronto le muerde rabiosamente el labio inferior del que sale la sangre a borbotones, derramándose por el cuello y el pecho de ella. (Nazarín, 19)

En coherencia con ello, vemos también en esta primera parte, y es algo que tampoco está en la novela, el intento de suicidio fallido de la amante abandonada. 
No es sólo el amor lo que aparece ahí, sino el deseo compulsivo, el «ello», en sentido freudiano, en su estado más explosivo; tiene esta imagen mucho en común con ese pasaje en el que a una mujer moribunda le da igual la otra vida, pero proclama su amor ciego por Juan, su amado.

El protagonista, muy fiel al de Galdós, se desvía, sin embargo, de su modelo, en su enfado final, distinto del de la novela -que en la última página nos deja al cura con una visión de Cristo que es prolegómeno del hombre que reaparece en Halma fiel a sus principios-. En la última secuencia de la película el cura se enfada y rechaza una piña que una mujer le ofrece, todo ello en medio del sonido de los tambores de Calanda. Buñuel entiende este final como una pregunta que nos presenta al bondadoso personaje de Paco Rabal sintiendo impulsos contradictorios (Turrent y De la Colina, 106), no sabemos si dejará su fe o no, pero siente humanos, «demasiado humanos», contradictorios impulsos. Siente una contradicción, está un escalón por debajo de la firmeza en la fe del cura de la novela, por muy cercano que este personaje le resulte a Buñuel (Turrent y De la Colina, 106), hay, en su ira final, una degradación con respecto al derrotado en el mundo pero triunfante en su interior personaje galdosiano.

Pero además de esa humanización que nos señala el propio cineasta, deberíamos ver en esta última secuencia una cierta animalización (para Buñuel lo más profundamente humano se acerca a lo animal) en esa ira del personaje, una reacción todavía contenida de animal acorralado que en Tristana se expresará ya sin límites.

En Nazarín estamos ante la degradación de un hombre bueno con el que simpatiza la mirada implícita de la película y con respecto al cual la degradación consiste no en una negación absoluta de sus valores, sino en una pregunta basada en su humanidad. Viridiana en algún sentido es una continuación de Nazarín, vuelve a aparecer en ella la preocupación de la fase espiritualista galdosiana por la entrega cristiana a los demás en un mundo moderno; sin embargo, en este segundo caso, la degradación del personaje es más demoledora y, con ello, claro, las reminiscencias sacrílegas de La Edad de Oro más claras. El personaje de Silvia Pinal no sólo duda, se desilusiona y, peor aún, termina en el dormitorio de un libertino cínico.

No es el caso de Nazarín, pero sí hay en Galdós otros personajes derrotados en sus pretensiones de santidad, la diferencia entre ellos y los de Buñuel está en la crudeza y tono, a veces blasfemo, del tratamiento que les da éste último.

Ángel Guerra muere, haciendo honor a su apellido, por no controlar su ira cuando le atracan tres delincuentes al final de la novela, del mismo modo que 
Catalina en Halma, en las últimas páginas tiene que admitir, bajo consejo de Nazarín, que no está preparada para la vida que se había propuesto, ajena a los humanos placeres de este mundo.

En Halma y Ángel Guerra podemos ver extendido al amor universal la idea que Julio Rodríguez Puertolas ha aplicado a las relaciones entre mujeres y hombres en Fortunata y Jacinta, y a la que ha llamado «doctrina del error» cervantino. Según dicha doctrina, los personajes de ésta novela tienen finales desgraciados porque, a causa de prejuicios sociales o, más importante en nuestro caso, por no medir bien sus propias posibilidades, no eligen el amor adecuado o dejan pasar el amor que les hubiese correspondido. La gente falla por forzar la naturaleza de las cosas y sus propias naturalezas, la frase del Quijote que selecciona Rodríguez Puértolas para definir dicha doctrina, «sufra y calle el que se atreve a más de a lo que sus fuerzas le prometen» (88), es más que adecuada para Catalina y Ángel Guerra; éste paga el error con la muerte; de hecho, en su novela hay muchas frases que preludian su violento final y que mucho se parecen en espíritu a la mencionada cita del Quijote. Al final de Ángel Guerra, el protagonista hace una especie de testamento vital que le escribe al sacerdote Don Juan en el que reconoce que él no está hecho para el amor místico y sí para el humano que no puede satisfacer por haberse enamorado por error de una mujer que por auténtica vocación religiosa no le puede corresponder: «Declaro que la única forma de aproximación que en realidad de mi ser me satisface plenamente, no es la mística, sino la humana, santificada por el sacramento, y que no siendo esto posible, desbarato el espejismo de mi vocación religiosa...» (692).

La condesa de Halma sí se salvará porque tiene un hombre que la ama y le corresponde cuando ella opta por el amor mundano, y porque encuentra el sabio consejo de Nazarín, quien dice estas palabras al que será esposo de Catalina en el momento en que ella ha descubierto que está hecha para el matrimonio en vez de para la vida mística:

Calma, hijo, no hagas locuras. Las cosas van por donde deben ir. Da gracias a Dios por haber iluminado a tu prima. Al fin comprende que debe llevarse la corriente de la vida por su cauce natural. Su determinación resuelve de un modo naturalísimo todas las dificultades que en el gobierno de esta ínsula surgieron (454).

A fin de cuentas lo que el autor implícito de estas obras de Galdós nos está pidiendo es el reconocimiento de la sombra. Subrayemos que el contradictorio nombre de Ángel Guerra ya contiene la sombra de este personaje que es su carácter violento (como parte de su humanidad) y que supone para él un límite mundano para su pretendida vida mística. 
Max Aub pensaba que Viridiana era una trasposición de Halma, algo que, por ejemplo, el coguionista de la película Julio Alejandro rechaza con matices, pues afirma que el guion de la película es original, pero digo con matices pues también señala el interés de Buñuel por dicha novela, tanto que pensó en su día en llevarla al cine y que «durante el trabajo que se hizo para el script de Nazarín se habló mucho de Halma» (Aub, 392). Desde luego, hay cosas en común y es más que lógico pues Halma es una continuación de la novela sobe el cura bondadoso y ya hemos visto los vínculos que existen entre los filmes Viridiana y Nazarín.

Lo que hacen al final la aristócrata galdosiana y el personaje de Silvia Pinal es parecido en el sentido en que ambas renuncian a sus aspiraciones de santidad y se dedican a la vida profana, pero hay muchos matices importantes y provocadores que señalar en el filme de Buñuel.

No basta con señalar el error de Viridiana, se va más allá de ello degradando intensamente al personaje que hemos visto al comienzo vestida de monja en un claustro y ahora entrando en la habitación del libertino que habita con la criada y, es posible, que participando en una relación de trío -claro que en esto tuvo su papel la censura franquista que no aceptó un final en el que Viridiana acudía a la habitación de Don Jorge y, sin embargo, tomó por más moral éste en el que los tres personajes juegan a las cartas en el dormitorio-.

«La doctrina del error» se complica de forma provocadora en las películas galdosianas del director aragonés porque no sólo se señala el error del idealismo, sino que se ejecuta un profundo ejercicio de degradación y se afirma el daño que el idealismo hace. Se pone en crisis, con crudeza, un aspecto capital del dualismo occidental, o sea, la oposición bien-mal, paralela a la polaridad luz-sombra.

Siempre que pienso en el sentido del bien y el mal en Viridiana, me viene a la mente la novela de Italo Calvino El vizconde demediado, ese aristócrata cuyo cuerpo es partido por una bala de cañón en dos mitades, una malvada y otra bondadosa, esta última por querer hacer el bien genera tanto mal como la otra. De esa escisión bondadosa hay mucho en Viridiana, que como si de una Pandora-Lulú de Pabst se tratase, produce un deseo mortífero; su caridad genera dos muertos. Es ciertamente nihilista el que un personaje que aspira a la santidad mate por el deseo que despierta, y no sólo eso, sino que la voluntad individual de hacer el bien queda aniquilada por sus resultados nocivos. Buñuel le aclara a Tomás Pérez Turrent y a José de la Colina, cuando estos le preguntan por la inutilidad de la caridad en su película, que en Viridiana se trata de un aspecto «contraproducente» de esta «porque produce catástrofes: el estropicio de la casa por los mendigos, riñas entre estos, la posible violación de Viridiana» (119). 
Más tímido es todo ello en Nazarín, pero también aparece en aquella secuencia (ajena a la novela) en la que el bondadoso sacerdote provoca una rebelión y tiros a causa de su humildad de no pedir ningún tipo de salario por trabajar. Demoledora es la frase del «ladrón bueno» que le dice al cura que su trabajo de nada sirve y que él seguirá siendo malo, a diferencia del Sacrílego de la novela que le protege en la cárcel y se convierte en fiel seguidor del cura.

Como dice Raquel Arias, Buñuel arremete contra la «espiritualidad y la religiosidad de forma mucho más virulenta» que la novela (74). La postura de Galdós con respecto a la caridad cristiana era una postura matizada, distinta de la del director de cine aragonés. Como demuestra Penuel en su estudio sobre la caridad en Galdós, don Benito pensaba que la justicia social debía predominar sobre la caridad y no ser una coartada ideológica: «He condems the attitude which allows the individual to be complacent about social injustice simply because he contributes to charity» (23). Pero al mismo tiempo valoraba ciertas formas de caridad en las que se mostraban auténticos valores cristianos. Esos valores que forman parte según Rodolfo Cardona del dominismo y que son los que conforman la ideología de Ángel Guerra:

... una nueva religión altruista para la humanidad en la que se vuelve a la caridad evangélica predicada por Cristo, observada por los cristianos primitivos, pero casi totalmente perdida en su posterior evolución ... las ideas fundamentales del dominismo se encuentran en los textos de los hermanos Lagarrique fechados con bastante antelación a la composición de Ángel Guerra, como se ha visto (93-94).

Por supuesto que Galdós somete a estas ideas doministas en sus novelas espirituales a muchos vaivenes propios del dialogismo de la mayor parte de sus obras, con triunfos (eso sí, individuales y místicos) como los de Nazarín y Benigna, y fracasos como el de Guerra. La posición de Buñuel con respecto a la caridad es menos matizada, no es que las películas galdosianas de Buñuel sean alegatos anticlericales, su posición de postvanguardista era ciertamente compleja en esta materia, pero da la sensación de que no puede evitar en ciertos momentos sacar su toque tajante, violento, degradante, nihilista, en definitiva, cuando toca estas materias - dice Buñuel de sí mismo a Aub «Sin embargo, cuando cierro los ojos yo soy un nihilista... Un nihilista total, un nihilista completo sin reservas de ninguna clase» (54)-.

Pero es en Tristana donde más claramente se marcan las distancias entre el director de cine y Galdós, aquí es la inmersión en la sombra de Buñuel la que más claramente marca las diferencias. Según Andrés Amorós «de un total de 35, 28 escenas (el 80 por ciento) son totalmente nuevas» (326). Algunas de estas 
diferencias vienen marcadas por el paso de la novela al cine, pero otras vienen marcadas por la propia crudeza.

Es en la forma extrema con que se abordan las emociones de los personajes donde la película se distancia más claramente del texto original. Emociones que, expresadas con toda su crudeza, hacen que el anciano y su pupila mantengan un romance intensamente destructivo, en una relación degradante que terminará con la muerte de uno de ellos.

La crudeza nos explica las inmensas variaciones que hay entre las dos tristanas. El personaje de Galdós acaba aceptando la realidad a la que la vida le ha llevado, reconoce su derrota. Poco a poco acepta y hace que su vida oscura con Don Lope se haga llevadera a través de la sublimación; transforma su amor por el pintor, tras sentirse abandonada por este, en amor a Dios y a la música. El argumento de la novela de Galdós es la historia de una derrota, pero una derrota que deja algunas puertas abiertas en su irónico, pero no cerrado, último párrafo, en el que leemos imágenes regeneradoras como el arbolito que planta el aburguesado Don Lope y la forma en que junto con su pareja celebra la salida de unos pollitos del cascarón (303). Ante la pregunta sobre la felicidad de ambos personajes, el narrador se responde con un «tal vez» que nos ofrece un final en el que hay duda y, por tanto, no un camino de definitiva perdición:

Por aquellos días entrole a la cojita una nueva afición: el arte culinario en su rama importante de repostería. Una maestra muy hábil enseñole dos o tres tipos de pasteles, y los hacía tan bien, tan bien, que don Lope, después de catarlos, se chupaba los dedos, y no cesaba de alabar a Dios. ¿Eran felices uno y otro?... Tal vez» (303-304).

El final del filme es demoledor, sin salida para el anciano, como suele suceder en los filmes de Buñuel en los que el deseo no es reprimido, pero sí castigado. Don Lope muere por la dejación consciente de una amargada Tristana que se venga de esa forma del daño que ha causado a su vida quien hubiese debido ser su protector.

Ambos textos tratan sobre la microfísica del poder en el espacio privado, en la casa y en el dormitorio además de la dificultad de encontrar una salida racional y colectiva a la dominación patriarcal impuesta por Don Lope. Todo poder conlleva una resistencia que en el texto literario se lleva a cabo a través de una forma más tenue, la sublimación, y en el filme de Buñuel, de forma más contundente, a través de la venganza.

La protagonista de Buñuel, tras perder su pierna y el amor de su amante, se vuelve rebelde e iracunda, se venga con un odio destructivo del personaje que ella considera que la ha dañado; pero no es la suya sólo una respuesta ante Lope, lo es ante el mundo, la recordamos en su silla de ruedas respondiendo despectiva, sin 
motivo aparente, a un señor burgués de provincias que le pregunta por su salud. El sonido, con el impacto seco del bastón y las muletas en el suelo, enfatiza muy bien este aspecto destructivo y tiránico del personaje de Deneuve.

La secuencia en la que más se extrema la diferencia entre el personaje del filme y el de la novela es aquella en la que Saturno acude a reclamar los favores del personaje de Deneuve y esta le dice que salga de la habitación. Después, Tristana le muestra su cuerpo mutilado desde el balcón al chico que abajo en el jardín se esconde entre ramas (quizás para masturbarse). Es una pasaje que no está en la novela.

Pero la tendencia a la crudeza se nos hace más manifiesta cuando vemos que entre el guion y la edición final del filme hay un salto en la depravación de sus personajes. Pues en el guion Tristana besa al chico y lo abraza, después le pide que se vaya de su habitación y no llega a mostrarle su cuerpo mutilado (respeto, numeración, sangría y uso de mayúsculas de la copia del guion de la Filmoteca Nacional):

233.- Ella lo ve acercarse sin hacer un movimiento de protesta. SATURNO queda parado un momento junto al lecho. Se inclina poco a poco hasta casi arrodillarse junto a la cama. Con su mano callosa comienza a acariciarla lentamente. Ella atrae la cabeza del hombre hacia la suya y lo besa desesperadamente. Quedan unidos ambos en un estrecho abrazo.

234.-De pronto vemos que en los ojos de la mujer se efectúa un cambio. La mirada se endurece, se hace más extraña y bruscamente intenta separarse del hombre. Al sentirse rechazado, SATURNO aprieta más el abrazo, pero ella lo empuja con fuerza y logra desasirse. Como SATURNO la observa asombrado, ella le ordena en voz baja, rencorosa:

\section{TRISTANA}

Y su brazo al mismo tiempo se extiende en dirección a la puerta.

¡Vete! ¡Vete inmediatamente!

En el resultado final en imágenes fílmicas se elimina el componente sentimental del beso desesperado y el abrazo, la eliminación del sentimentalismo incrementa la frialdad y, por ende, la crudeza. Esta eliminación de lo sentimental crea distanciamiento y una visión fría de la secuencia. Distanciamiento que hace más temible al personaje. En el montaje final Tristana invita al chico a salir de la habitación y le muestra su cuerpo abriéndose la bata con un mohín, una sonrisa demoniaca que da el tono a la escena, lo terrible de la misma no deja de estar bañada de una tenue luz de comicidad que incrementa, a su vez, el extrañamiento.

Por otro lado, el filme no nos brinda antecedentes sobre la relación entre la protagonista y el chico, lo que aumenta el componente sorpresivo y, por tanto, generador de extrañamiento de la secuencia. No hay casi palabras para hacer más compresible la situación porque Saturno es mudo. Es el dominio de la imagen, 
que al no tener el complemento de la palabra se hace más oscura; el dominio de la imagen impactante que, precisamente, por su relación oscura con la palabra no cae en la evidencia. De la relación entre estos dos personajes solo tenemos una premonición con cierta carga de ironía bíblica en la que ella le da al joven una manzana cuando se conocen al comienzo del filme. De nuevo, esa sonrisa demoníaca que baña tenuemente los filmes de Buñuel.

El ambiente de degradación del filme se incrementa si ponemos esta secuencia en contacto con las inmediatamente anterior y posterior, ambas tienen que ver con la boda. En la escena previa, un cura, de modo paternalista, le dice a Tristana que termine con su situación irregular y se case con Don Lope, e inmediatamente después del pasaje sórdido entre la protagonista y Saturno, vemos una secuencia en la que, en contraste blasfemo con la crudeza de la anterior, aparecen imágenes de la Virgen en la iglesia donde se celebra la desabrida boda con el personaje de Fernando Rey. En el guion sí aparece la boda justo después del beso y posterior rechazo a Saturno, pero no los planos de las vírgenes, lo que de nuevo indica un corrimiento hacia la crudeza en el montaje final.

En general, las últimas secuencias de la película están gobernadas por el misterio de la vida sin sentido, sin explicación. Esta falta de claridad hace que el mundo cotidiano de Toledo en los años treinta se vuelva extraño, se desfamiliarice, se distancie; según Kayser, para que haya distanciamiento en la expresión artística, «deben revelarse de pronto como extrañas y siniestras las cosas que antes nos eran conocidas y familiares» (224).

En el descarnamiento de Buñuel está implícita una visión de entomólogo que estudia distante los instintos de sus personajes sin definirnos el sentido moral de sus comportamientos, al comentar la visión implícita de ciertas partes de esta película vienen a la mente las palabras del mencionado Kayser sobre la mirada grotesca a la que considera una «mirada fría con la que se contemplaba el trajín del mundo, concibiéndolo como un juego de muñecos, huero y carente de sentido, un teatro caricaturesco de títeres» (226).

Títeres en los que se mezcla lo cómico y lo terrible, esa contradictoriedad, esa fusión de lo que no ha de ser mezclado, incrementa el sentido de la extrañeza. Ya, Ruskin, en el siglo XIX definía esta contradictoriedad como característica de lo grotesco: «First, then, it seems to me that the grotesque is, in almost all cases, composed of two elements, one ludicrous, the other fearful; ...» (126).

En la secuencia que analizo, se nos conduce a una sensación de desfamiliarización sórdida que a su vez nos conecta con las partes más ocultas de la emoción. Esto que Geoffrey Harpham dice con respecto a los textos de arte 
grotescos, en general, puede ser aplicado a muchas secuencias de la filmografía del director de Calanda: «jeopardize or shatter our conventions by opening onto vertiginous new perspectives characterized by the destruction of logic and regression to the unconscious - madness, hysteria, or nightmare» (462).

Efectivamente, la sombra es interpelada y términos como fetichismo, sadomasoquismo, o la interacción Eros - Tánatos, vienen a la mente cuando pensamos en la pierna ortopédica (muerta) de ella junto a la ropa interior en la secuencia de la seducción de Saturno; en el sueño en el que la protagonista ve la cabeza cortada de Don Lope como un badajo de campana; en la evolución de Don Lope, dominante al comienzo y sumiso hasta la humillación y en el asesinato del mismo al final de la película, entre otras secuencias que podríamos citar. Sobresale en este sentido la interpelación a la interacción de Eros y Tánatos en la secuencia que termina con el primer beso de Don Lope a Tristana, cuando esta se posa sobre la estatua mortuoria del cardenal Tavera; en ella, tras un primer plano del rostro de la escultura, vemos otro primer plano en el que se ve muy próxima la cara de la protagonista sobre la del cardenal de piedra. Son imágenes con un fuerte poder condensatorio. Toda la relación viciada por el deseo entreverado con el poder, el odio y la muerte que vamos a ver a partir de esta secuencia, se encuentra sintetizada en este plano. El cine de Buñuel posee el poder condensatorio que tienen las imágenes de los sueños, según la influyente interpretación de los mismos que hace Freud, no en vano, el director de Un perro andaluz sintió siempre profunda fascinación por lo onírico y estableció en diversas ocasiones analogías entre la ensoñación y la imagen cinematográfica.

En lo referente a la degradación, es muy significativo el protagonismo que en esta secuencia tiene Saturno, el adolescente hijo de la criada, casi inexistente por contraste en la novela. El nombre de este chico, además de ser entendido como el masculino de Saturna, su madre, tiene, por otro lado, la resonancia del dios de las saturnales y de la oscuridad preolímpica. El joven Saturno vive en el puro deseo, se mueve por impulsos del «ello», como los chicos de ciudad de Méjico en Los olvidados o los mendigos que atacan a Viridiana. Este Saturno prefiere masturbarse en el retrete a trabajar y es como una exacerbación de los principios que mueven a Don Lope y a Tristana. El «ello» (el «id») freudiano, pero también podemos hablar del «id» de Kayser, según este teórico alemán los hilos del mundo del extrañamiento son movidos como marionetas por la fuerza oculta de un «ello»

La pierna de la protagonista es según Raquel Arias el símbolo central de la novela que adquiere «tintes morbosos» (78) en el filme de Buñuel. Efectivamente, en la secuencia en que Tristana muestra su cuerpo a Saturno, esa pierna, encima 
de la cama, se convierte en un componente altamente connotativo del espacio fílmico. Esa pierna artificial es un compuesto de materia muerta, un fetiche, un derivado sin vida de la pierna de carne. Del mismo modo, no es pierna, no es carne de carnestolenda lo que hay en la exhibición del cuerpo mutilado, sino carencia de pierna. Sobre la carne se ha impuesto un objeto inanimado, la pierna ortopédica que vemos junto a la ropa interior. Viene a la mente la palabra «descarnada», en el doble sentido, de pierna sin carne y de visión descarnada del mundo que es la que continuamente surge al escribir sobre la idiosincrasia de Luis Buñuel. Como antiguo surrealista se burla de la represión, pero su visión del deseo no es en absoluto alegre, porque solo aparece en su cinematografía como un «id» que dirige a las marionetas llevadas por él. El deseo es uno de los componentes fundamentales del mundo de las sombras en Buñuel.

\section{BIBLIOGRAFÍA}

Alejandro, J. y Buñuel, L. (1959). Nazarín (guion). Copia de la Filmoteca Nacional con anotaciones de Luis Buñuel.

. Tristana (guion). (1969). Copia de la Filmoteca Nacional con anotaciones manuscritas.

. Viridiana (guion). (1995). Madrid: Alma-Plot.

Amorós, A. (1977). «Tristana, de Galdós a Buñuel». Actas del Primer Congreso Internacional de Estudios Galdosianos, 319-329.

Arias, R. (2020). «¿Qué vio Buñuel en Galdós?». Revista de Occidente, 473, 67-80.

Birkhäuser-Oeri, S. (2011). La llave de Oro. Madres y madrastras en los cuentos infantiles. Traducción de Ruth Zauner. Madrid: Turner.

Buñuel, L. (1993). Buñuel por Buñuel. Entr. José de la Colina y Tomás Pérez Turrent. Madrid: PLOT.

. (1985). Conversaciones con Buñuel. Entr. Max Aub. Madrid: Aguilar.

Cardona, R. (1998). Galdós ante la literatura y la historia. Las Palmas de Gran 
Canaria: Cabildo Insular de Gran Canaria.

Calvino, I. (1999). El vizconde demediado. Traducción de Esther Benítez. Madrid: Siruela.

Chatman, S. (1990). Coming to Terms. The Rhetoric of Narrative in Fiction and Film. Ithaca/London: Cornell University Press.

Freud, S. (1996). «Lo siniestro». Obras Completas. Tomo III. Traducción de L. Ballesteros. Madrid: Biblioteca Nueva.

Fuentes, V. (2005). La mirada de Buñuel, Cine, literatura y vida. Madrid: Tabla Rasa. Han, B. (2019). Hegel y el poder: Un ensayo sobre la amabilidad. Barcelona: Herder. Harpham, G. (1976). «The Grotesque: First Principles». The Journal of Aesthetics and Art Criticism, 34.4, 461-468.

Jung, C. G. (1970). Arquetipos e inconsciente colectivo. Traducción de Miguel Murmis. Barcelona: Paidós.

Kaiser, W. (1964). Lo grotesco: su configuración en pintura y literatura. Buenos Aires: Losada.

Nazarín (1959). Dir. Luis Buñuel. CLASA. DVD.

Penuel, A. (1972). Charity in the novels of Galdós. Athens: University of Georgia Press.

Pérez Galdós, B. (2008). Ángel Guerra. Barcelona: RBA, Instituto Cervantes. . (2008). Nazarín. Barcelona: RBA, Instituto Cervantes. . (2011)Tristana. Edición de Raquel Arias. Madrid: Akal.

Rodríguez Puértolas, J. (1975). Galdós: burguesía y revolución. Madrid: Turner. Ruskin, J. (1886). The stones of Venice. Vol. III. 4aㅡ edición. London: George Allen. Tristana (1970). Dir. Luis Buñuel. Maron Films. DVD.

Viridiana (1961). Dir. Luis Buñuel. Kingsley-International Pictures. DVD. 